\title{
Motivation, Self-Perception of Success and Attitudes of Amateur Swimmers
}

\author{
Everton Rodrigues Lopes ${ }^{1}$, Rodrigo Silva Campos ${ }^{1}$, Lucas De Andrade Guedes Barros ${ }^{1}$, Carlos \\ Eduardo Lopes Verardi ${ }^{2}$, Ademir De Marco ${ }^{3}$, Vinicius Barroso Hirota ${ }^{1^{*}}$ \\ ${ }^{1}$ Research Member of Brazilian Paralympic Academy - São Paulo, Brazil \\ ${ }^{2}$ Sciences College, Department of Physical Education, Paulista State University (UNESP) - Baurú, Brazil \\ ${ }^{3}$ Department of Physical Education - UNICAMP - Campinas, Brazil
}

*Corresponding Author: Vinicius Barroso Hirota, Research Member of Brazilian Paralympic Academy - São Paulo, Brazil

\begin{abstract}
The aim of the research was describing the motivational orientation profile (task orientation and ego orientation), verify self-perception of success and observe the attitudes (positive and negative) of adult amateur swimmers. Subsequently as a specific objective, correlate the obtained data. The methodological procedure used was a correlational research of descriptive character with 24 (n:24) participants aged between 20 and 64 years (mean 31.66 \pm 11.51 years old); the instruments used was TEOSQ, POSQp and a Sports Scale Attitude all validated. We used as statistical treatment the calculation of the Cronbach Alpha's Coefficient in order to confirm the reliability, Mann-Whitney and Spearman correlation. The results show a great performance of the reliability of the instruments, TEOSQ task Alfa's 0.75, and ego's Alfa 0.81, POSQp task's Alpha 0.88 and ego's Alpha 0.84 and Sports Scale Attitude Alpha's Positive Attitudes 0.96 and Alpha's Negative Attitudes of 0.762. The average of task orientation both from TEOSQ, POSQp and positive attitudes was higher than negative attitudes and ego orientation. The motivational orientation model that determines the task, so they used to work more and harder and like to compete. Strategies and General State Anxiety between them.
\end{abstract}

Keywords: Swimming, Motivation, Self-Perception of Success, Attitudes

\section{INTRODUCTION}

In the case of this article we return our study to the liquid medium, which in the view of Avellini et al. (1983) one can expect that the aquatic physical exercise that produces different physiological reactions to the open air due to both the hydrostatic effect of water in the cardio respiratory systems and its ability to intensify heat loss compared to air.

There are a number of factors that induce people to start and stay in a physical activity program. These are divided into non-modifiable factors, such as age, gender, race and ethnicity, and on modifiable factors such as learning, personality characteristics, environmental circumstances and the social environment. Influence factors are multifactorial and may vary according to the type, intensity of physical activity and during the phases of involvement in practice. Our body is adaptable and so every day we need it to work so that it stays active, the racial differences are an example: the increase of melanin, the eyes pulled, etc. This happens with time and with the environment in which it was exposed. With this, the human organism can in essence be considered as a complex society of cells of very diverse types and are associated and interrelated, structurally and functionally, in a huge variety of means, in order to perform functions indispensable to the organism survive as a whole (Kruel et al., 1995).

For a long time, success in youth sports seems to depend on the motivation and satisfaction they demonstrate during practice and in fact, athletes' sporting experiences are influenced by their own perceptions of the surrounding environment and in turn influence their behaviors. Sport values man socially, provides an improvement of his self-concept and learning a sports modality is one of the most experiences that the human being can live with his own body. As Moretti and Treichell (2003) emphasize that the human being brings with it feelings, ambitions; creates expectations, gets involved, seeks growth within what he develops and realizes. 
Hirota et al. (2012) emphasize that the elements of the environment together with momentary situations lead an individual to perform a particular action or not. Within this context, the possibilities of overcoming, due to the intermittency characterized by the sport can make the practitioners demonstrate aspects related to self-determination and re-elaboration of their motor skills, adapting to the challenges, always seeking self-fulfillment in the context.

Mosquera and Stobäus (2006) says that people who have a tendency to self-realization even come to differentiate themselves from the environment, especially through transactions and transitions in it. Gouvêa (1997) adds that people who have a high level of motivation for achievement demonstrate, through words and actions, a search for the standard of excellence. For a coach, this individual, in the competition, would have as goal the success and a better sport performance. Lavoura (2007) say that athletes considered more technical or more skilled perceive better their abilities to evaluate their conditions to carry out a certain action successfully. The reason for the achievement is often considered a reason for growth (Paim, 2001).

Thus goal achievement theory (Nichlos, 1984, 1989) assumes that individuals are goal oriented and operate in a rational way, suggesting that individuals can guide their motivation in two ways (ego orientation and orientation towards depending on the criteria by which they evaluate their competence and define the success of their participation in a particular activity, in a context of achievement.

Orientation to the ego is related when a person is oriented primarily to demonstrate more income than others, and the goal of task orientation, when orientation is linked to learning or to perform a task mastery, i. e., seeks self-overcome (Duda, 1992).

The emotional expression of practitioners may differ according to cultural situations, motivational components and momentary moods and, in the case of adventure activities, are associated with the concepts of risk and safety that the activities offer (Schwartz, Carnicelli Filho, 2006). Due to this problem of motivational reflex, of sports practice we aim in this study to observe what kind of motivational orientation of goals that a certain group of swimmers present. Santos (2008) carried out a study about the motivational factors that kept the individuals in competitive practice and these motivations changed with the years of practice.

With this, our study approaches the motivation in the aquatic area, we know that this psychological aspect influences in the practice of physical activity, in self-sufficiency, leisure and even in education. The unmotivated individual tends to modify self-image, making it less positive, whose motive is still ignored. Self-image and self-esteem are interrelated, dependent on one another, and vary according to gender. They reflect the social roles occupied by the individual. When self-esteem is high, it stems from positive experiences with life; On the other hand, when self-esteem is low, it results from negative factors. Self-image is always changing, as the individual acquires experiences in everyday life, occupational and leisure. Due to this problem of motivational reflex, of sports practice we aim in this study to observe what kind of motivational orientation of goals that a certain group of swimmers present.

In this way the aim of the research is describe the motivational orientation profile (task orientation and ego orientation), verify self-perception of success and observe the attitudes (positive and negative) of adult amateur swimmers. Subsequently as a specific objective, correlate the obtained data.

\section{METHOD}

\subsection{Study Model}

This research is framed in correlational studies, which according to Thomas and Nelson (2002) the proposal from correlational research is to examine the relationship between certain variables, such as the correlation between attitudes and behavior, but the study has a descriptive character (Gil, 1999).

\subsection{Sample}

A total of 24 participants (n:24) aged between 20 and 64 years (mean 31.66 \pm 11.51 years, coefficient of variation of 36.35\%) made up the study. Of these, 20 men aged between 20 and 64 years (mean $32.15 \pm 16.03$ years, coefficient of variation of $49.86 \%$ ) and 4 women aged between 24 and 37 years (mean 29.25 \pm 4.96 years, coefficient of variation of $16.95 \%$ ), so the data presented were homogeneous in relation to the age of the study participants only in relation to the women. The sample was collected in a gymnasium in the south zone of. the participants had the free and informed consent term, in this way all ethical research care was taken. 


\subsection{Instruments}

- Instrument 01: Task and Ego Orientation of Sport Questionnaire - TEOSQ developed by Duda (1992), translated, adapted and validated for Portuguese (Brazil) by Hirota et al. (2006) and Hirota and De Marco (2006). The purpose of TEOSQ is to evaluate individual differences in goal perspectives, adjusted to the practice of sports, verifying the motivational orientation of the sportsman being task-oriented or to ego-oriented (Duda, 1992). This instrument allows to identify the motivational orientation of the sportsmen in front of the execution of a task, that is, the interviewees must face the sport that trains and evaluate how successful it is in this modality. The TEOSQ consists of 13 Likert-type questions of 5 points (varying according to the level of agreement with each one), with 06 questions referring to ego orientation, or fear of failure, and 07 questions regarding task orientation, or expectation of success. The time taken to respond to the instrument is approximately 5 minutes, this instrument being self-filling.

- Instrument 02: Attitude Scale (EAA) in relation to the proposed sports competition, adapted and validated by Brito (1998), a four-point Likert type scale, composed of 20 items (10 negative and 10 positive) whose purpose was to assess the attitudes with relationship to a like or dislike to compete in swimming. This instrument was adapted for sport competitions by Hirota, et al. (2014); this instrument is also self-administered and has an average response time of 7 minutes for the participant.

- Instrument 03: scale named Portuguese Perception of Sucess Questionnaire (POSQp) was translated into Portuguese as Quiz About Success perception adapted to the Brazilian reality and had its psychometric properties tested by Fonseca and Balagué (2001) and Fonseca and Brito (2001). This instrument followed the same TEOSQ grouping direction: task orientation and ego orientation. The scale consists of a total of 12 Likert five-point questions, in which 1 represents "totally disagreeing", and value 5 "fully agrees", in this perspective we turn to an instrument that evaluated self-perception of success, an instrument that has theoretical premises of cognitive social motivation (Fonseca; Balagué, 2001). This is also a selfcompletion scale and the expected time to respond is approximately 5 minutes.

\subsection{Statistical Treatment}

We used as statistical treatment the calculation of the Cronbach Alpha's Coefficient in order to confirm the reliability of the scale, testing the legitimacy of the instrument in front of the subjects involved in the study. In order to see possible significant differences between the means of the Task and Ego goals and positive and negative attitudes, we chose to perform the Mann-Whitney test with significance level of $p \leq 0.05$, separately for each orientation, that is, goal orientation task and meta-ego orientation, with the exception of the existence of significant differences between genders. For correlation, Spearman correlation ( $r h o$ ) was calculated with significance level of $p \leq 0.01$ and $p \leq 0.05$.

\section{RESULTS AND DiSCUSSION}

Regarding the tests of the internal consistency of the instruments, we obtained the following results:

- TEOSQ: Alfa's task 0.754 (F: 37.873, $p=0.001$ ) and Alfa's ego 0.811 (F: 53.121, $p=0.001$ );

- POSQp: Alpha's Task 0.882 (F: 1.350, p= 0.248) and Alpha's Ego 0.843 (F: 5.325, $p=$ $0.001)$

- Sports Scale Attitude: Alpha's Positive Attitudes 0.960 (F: 4.540, $p=0.001$ ) and Alpha's Negative Attitudes of 0.762 (F: 4.956, $p=0.001$ ).

As we can see, all Alpha's coefficient results exceed the expected reference value; the minimum acceptable value for alpha is 0.70 ; values between 0.80 and 0.90 are usually preferred (Streiner, 2003). In Table 01, we can verify significantly higher values of task orientation for both POSQp and TEOSQ (4.65 \pm 0.60 and $4.35 \pm 0.85$ ), as well as a mean of positive attitudes towards sports competitions also higher $(3.14 \pm 2,17)$. In Table 01 all the means results are significant different in each sub-scale.

Median values were higher, reaching a maximum value for POSQp and TEOSQ (value of 5) and attitudes scale, reaching a value of 3 (maximum possible value would be 4 ). In the results of egoorientation, the values fit in with the literature (Duda, 1992; Hirota, 2014, Klain, et al., 2014, LopezWalle et al., 2011; Hirota et al., 2011). Similar results were found recently in a study by Amaro et al. 
(2017) with elite swimmers with a task average of 4.92 and ego of 3.94, and positive attitudes of 3.72 , and negative attitudes of 1.51 .

Table1. Results of mean, standard deviation, median, score and comparison of both subdivisions of the instruments

\begin{tabular}{|c|c|c|c|c|c|c|}
\hline Scales & Sub-Scales & Mean & S. Dev. & Median & Score & $\boldsymbol{P}(\leq 0.01)$ \\
\hline \multirow{3}{*}{ POSQp } & Task & 4.65 & 0.60 & 5 & 27.95 & \multirow{2}{*}{$\mathbf{0 . 0 0 1}$} \\
\cline { 2 - 6 } & Ego & 3.25 & 1.13 & 3 & 19.54 & \\
\cline { 2 - 6 } & Positive & 3.14 & 2.17 & 3 & 31.45 & \multirow{2}{*}{$\mathbf{0 . 0 0 1 *}$} \\
\cline { 2 - 6 } TEOSQ & Negative & 2.17 & 0.84 & 2 & 21.7 & \\
\cline { 2 - 6 } & Task & 4.35 & 0.85 & 5 & 26.12 & $\mathbf{0 . 0 0 1 *}$ \\
\hline
\end{tabular}

Observing the correlation results between the task orientation and ego orientation of TEOSQ, we found that the result was negative, moderate and significant ( $r h o=-0.249 ; p \leq 0.01)$, demonstrating that as the task orientation consolidates ego orientation tends to diminish, that is, apparently as individual's train more, learn more, they raise their self-confidence. This result was evidenced in the scale of self-perception of success in the correlation between task orientation and ego orientation ( $r h o=0.298 ; p \leq 0.01$ ), thus demonstrating similar postures of swimmers; there is a tendency between task orientation and also the task of self-perception of success, since both orientations suggest a positive but weak correlation. Complementing the correlation between task orientation and attitudes to compete in the sport, a weak, positive and significant result $(r h o=0.210 ; p \leq 0.01)$ was evidenced, thus consolidating our hypothesis that task-oriented, because they are athletes who train more persist more and tend to run after their goals, are less afraid of competing, and tend to demonstrate more determined attitudes.

Table2. Correlation results between the scales and their subdivisions.

\begin{tabular}{|c|l|l|l|l|l|l|l|}
\hline \multicolumn{2}{|c|}{$\begin{array}{c}\text { Correlation "rho" } \\
*\end{array} \boldsymbol{p} \leq \mathbf{0 . 0 5} ; * * \boldsymbol{p} \leq \mathbf{0 . 0 1}$} & \multicolumn{2}{c|}{ TEOSQ } & \multicolumn{2}{c|}{ POSQp } & \multicolumn{2}{c|}{ ATT } \\
\cline { 2 - 8 } & Task & Ego & \multicolumn{1}{c|}{ Task } & Ego & Negative & Positive \\
\hline \multirow{2}{*}{ TEOSQ } & Task & 1 & $-.249 * *$ & 0.115 & $.298^{* *}$ & -0.119 & $.210^{* *}$ \\
\cline { 2 - 8 } & Ego & & 1 & $.274 * *$ & -0.043 & 0.011 & $.258^{* *}$ \\
\hline \multirow{2}{*}{ POSQp } & Task & & & 1 & $.303 * *$ & 0.005 & $.358^{* *}$ \\
\cline { 2 - 8 } & Ego & & & & 1 & $-.187 *$ & $.386^{* *}$ \\
\hline \multirow{2}{*}{ ATT } & Negative & & & & & 1 & $-.128^{*}$ \\
\cline { 2 - 8 } & Positive & & & & & & 1 \\
\hline
\end{tabular}

Correlating TEOSQ ego orientation and POSQp task orientation the result was positive, weak but significant $(r h o=0.274 ; p \leq 0.01)$; in relation to the ego orientation of TEOSQ and POSQp the result was very weak, positive and not significant, just as it was expected that ego-oriented subjects were less willing to compete or did not like sports competitions, however the correlation was positive, weak and significant ( $r h o=0.258 ; p \leq 0.01$ ), that is, we can justify this fact the sporting modality, because it is of an individual character, and the spirit of cooperation eventually be left aside to the detriment of the development itself, and individual performance against opponents.

Pelletier et al. (1995) reinforces this idea when he says that individuals motivated intrinsically participate in a sport because they consider interesting or want to learn more about it, or for the pleasure of trying to overcome is themselves. Those who are task-oriented are focused on improving their personal skills, and realize that competence is governed by self-referenced criteria (Nicholls, 1984, 1989).

Individuals who are ego oriented are focused on the outcome that comes from their involvement in the task, and realize that competence results from comparison with others (Nicholls, 1984); Smith et al. (2006) report that a moderate/ high ego orientation, when complemented with a high task orientation, does not necessarily lead to maladaptive behavior strategies, since it also produces feelings of fun and satisfaction with the practice of the modality, the same finding in our study was found.

When we compare the self-perception of success among its sub-scales, that is, task orientation and ego orientation, we verify exactly what happens in the previous citation, that is, the correlation was moderate, positive and significant $(r h o=0.303 ; p \leq 0.01)$, thus raising the task condition and consequently increased ego, and once again the hypothesis was confirmed of better prepared and confident athletes if they like to compete, showing positive, moderate and significant results ( $r h o=0.358 ; p \leq 0.01$ ), so these individuals do not feel terrified by the competitions. correlating the 
POSQp instrument's ego orientation and sports attitudes, we show that there is a negative, weak but significant correlation with negative attitudes $(r h o=-0.187 ; p \leq 0.05)$, as well as in the TEOSQ instrument, in the orientation variable for (POSQp) and positive attitudes there was a positive, moderate and significant correlation ( $r h o=0.386 ; p \leq 0.01)$, demonstrating an attempt to involve competitions of both types of orientation, even if they do not like to compete.

Finally, the correlation between negative and positive attitudes was found a negative one, weak and significant result ( $r h o=-0.128 ; p \leq 0.05$ ), that is, as positive attitudes increase, negative, even if shyly. These results tend to be influenced by the ego orientation of both scales (TEOSQ and POSQp), since in individual sports, it is difficult to posture a restricted or exclusive focus on the individual, since although athletes tend to it is not linked to the group, or in the work of a team, so we admit that athletes oriented to the ego, present features of their own performance with opponents.

Being thus people with high values of perception of competence, tend to have characteristics directed to the orientation to task, that is to say, they are more satisfied with their experience and sports practice, for this reason they tend to train more and devote to the routine of the training. Task-oriented athletes feel more successful when they demonstrate a clear improvement in their performance, and the ego-oriented ones feel more successful when they defeat their opponents (Fonseca; Brito, 2001); therefore, task-oriented comparison of self-performance in relation to learning / effort.

Aparicio et al. (2004), says that the relationship between attitudes and performance is bidirectional and complex. It is understandable, then, that students who perform well on a particular subject tend to have more positive attitudes towards it, as well as those with more positive attitudes tend to perform better, and vice versa. Consequently, Huffman et al. (2003), elucidates that our attitudes are learned, in this way can be modified with time, not being permanent; for this to happen requires an effort of persuasion, or cognitive dissonance, in which it explains that it is a perceived discrepancy between an attitude and behavior or between an attitude and a new information.

\section{CONCLUSION}

According to the obtained data with the three instruments, it is clear that there is a motivational orientation model that determines the task, thus demonstrating that these swimmers try harder to learn and train; they have a positive self-perception of success, that is, they seek to train more to improve their performance or quality of life, and when exposed to the competitive process, they deal well with the challenges and adversities encountered.

\section{REFERENCES}

[1] Amaro, L. A., Prado, P. A., Paiano, R., Verardi, C. E. L., Larizzatti, M. F., \& Hirota, V. B. (2017). Correlation between goal orientation and attitudes of Brazilian elite swimmers. Journal of Physical Education and Sport, 17(2), 783.

[2] Aparicio, A., Bazán, J., \& Abdounur, O. (2004). Atitude e desempenho em relação à Estatística em professores de Ensino Fundamental no Peru: primeiros resultados. Encontro Paulista de Educação Matemática, 7. Faculdade de Educação Universidade de São Paulo.

[3] Avellini, B. A., Shapiro, Y., \& Pandolf, K. B. (1983). Cardio-respiratory physical training in water and on land. European journal of applied physiology and occupational physiology, 50(2), 255-263.

[4] Brito, M. D. (1998). Adaptação e validação de uma escala de atitudes em relação à matemática. Zetetiké, 6(9), 109-162.

[5] Duda, J. L. (1992). Motivation in sport settings: A goal perspective approach. In ROBERTS, G. C. (1992) Motivation in Sport and exercise. Illinois: Human Kinetics Books.

[6] Fonseca, A., \& Balagué, G. (2001). Avaliação dos objectivos de realização no futebol juvenil de competição: Comparação entre o TEOSQp e o POSQp. A FCDEF-UP e a Psicologia do Desporto: Estudos sobre motivação, 59-62.

[7] Fonseca, A., \& Brito, A. (2001). Estudo exploratório e confirmatório à estrutura factorial da versão portuguesa do Perception of Sucess Questionnaire (POSQ). Revista Portuguesa de Ciências do Desporto, 1(3), 61-69.

[8] Gil, A. C. (1999). Métodos e técnicas de pesquisa social. São Paulo: Atlas, p.44-165.

[9] Gouvêa, F. C. (1997). A motivação e o esporte: uma análise inicial. In: BURITI, M. de A. Psicologia do Esporte. Campinas: Alínea, 149-173.

[10] Hirota, V. B., Schindler, P., \& Villar, V. (2006). Motivação em atletas universitárias do sexo feminino praticantes de futebol de campo: um estudo piloto. Revista Mackenzie de Educação Física e Esporte, 5(3). 
[11] Hirota, V. B., \& De Marco, A. (2006). Identificação do clima motivacional em escolas públicas e particulares na aprendizagem esportiva no futebol de campo: um estudo piloto. Revista Brasileira de Educação Física e Esporte, 20(5), 123-133.

[12] Hirota, V. B., Hayashi, D. H., Marco, A. D., \& Verardi, C. E. L. (2011). The influence of motivational orientation during training of novice athletes in tennis field. Revista Mackenzie de Educação Física e Esporte, 6(3), 11-20.

[13] Hirota, V. B., Verardi, C. E. L., \& De Marco, A. (2012). Orientação motivacional de metas na modalidade do basquetebol. Educação Física em Revista, 6(3).

[14] Hirota, V. B. (2014). Goal orientation of Brazilian skateboarders. Journal of Physical Education and Sport Management, 5(1), 1-4.

[15] Hirota, V. B., Diniz, D. V., Silva, M. R. D., Lima, R. O. D., Verardi, C. E. L., \& De Marco, A. (2014). Initial stages of attitude's instrument adaptation to brazilian sports competitions. International Journal of Physical Education, Sports and Health, 1(1), 10-13.

[16] Huffman, K.; Vernoy, M.; Vernoy, J. (2003). Psicologia. São Paulo: Atlas.

[17] Klain, I. P., Cid, L., Matos, D. G. D., Leitão, J. C., Hickner, R. C., \& Moutão, J. (2014). Motivational climate, goal orientation and exercise adherence in fitness centers and personal training contexts. Motriz: Revista de Educação Física, 20(3), 249-256.

[18] Kruel, L., Avila, A., Da Silva, J. H. S., \& Sampedro, R. (1995). Peso Hidrostático em pessoas submetidas a diferentes profundidades de água. IN. In Anais do VI Congresso Brasileiro de Biomecânica. Brasília. Pp (pp. 197-205).

[19] Lavoura, T. N. (2007). Estados Emocionais: A Investigação do medo no contexto esportivo. Dissertação de mestrado UNESP.

[20] López-Walle, J., Tristán, J., Isabel Castillo, I. T., \& Balaguer, I. (2011). Invarianza factorial del TEOSQ en jóvenes deportistas mexicanos y españoles. Revista Mexicana de Psicología, 28(1).

[21] Moretti, S., \& Treichel, A. (2003). Qualidade de vida no trabalho x auto realização humana. Revista Leonardo pós-Órgão de Divulgação Científica e Cultural do ICPG, Blumenau, 1(3), 73-80.

[22] Mosquera, J. J. M., \& Stobäus, C. D. (2006). Auto-imagem, auto-estima e auto-realização: qualidade de vida na universidade. Psicologia, saúde e doenças, 7(1), 83-88.

[23] Nicholls, J. G. (1984). Achievement motivation: Conceptions of ability, subjective experience, task choice, and performance. Psychological Review, 91(3), 328.

[24] Nicholls, J. G. (1989). Conceptions of ability and achievement motivation. In: Ames, R.; Ames, C. (1989) (Eds.). Research on Motivation in education: Student Motivation, v. 01. New York: Academic Press.

[25] Paim, M. C. C. (2001). Fatores motivacionais e desempenho no futebol. Journal of Physical Education, 12(2), 73-79.

[26] Pelletier, L. G., Tuson, K. M., Fortier, M. S., Vallerand, R. J., Briere, N. M., \& Blais, M. R. (1995). Toward a new measure of intrinsic motivation, extrinsic motivation, and amotivation in sports: The Sport Motivation Scale (SMS). Journal of sport and Exercise Psychology, 17(1), 35-53.

[27] Santos, S. (2008). A motivação subjacente para a continuidade da modalidade desportiva. Portal dos psicólogos.

[28] Smith, A. L., Balaguer, I., \& Duda, J. L. (2006). Goal orientation profile differences on perceived motivational climate, perceived peer relationships, and motivation-related responses of youth athletes. Journal of Sports Sciences, 24(12), 1315-1327.

[29] Streiner, D. L. (2003). Being inconsistent about consistency: When coefficient alpha does and doesn't matter. Journal of personality assessment, 80(3), 217-222.

[30] Schwartz, G. M., \& Carnicelli Filho, S. (2006). (Desin) Formação profissional e atividades de aventura: focalizando os guias de "Rafting". Revista Brasileira de Educação Física e Esporte, 20(2), 103-109.

[31] Thomas, J. R.; Nelson, J. K. (2002). Métodos de pesquisa em atividade física. Porto Alegre: Artmed.

Citation: Vinicius Barroso Hirota, et.al. "Motivation, Self-Perception of Success and Attitudes of Amateur Swimmers " International Journal of Sports and Physical Education (IJSPE), vol 5, no.1, 2019, pp. 7-12. doi: http://dx.doi.org/ 10.20431/2454-6380.0501002.

Copyright: (C) 2019 Authors. This is an open-access article distributed under the terms of the Creative Commons Attribution License, which permits unrestricted use, distribution, and reproduction in any medium, provided the original author and source are credited. 